\title{
Another Dimension to Slump
}

\author{
A.J. Vietti, F. Dunn Paterson and Cooke Consulting Scientists (Pty) Ltd, South Africa
}

\section{INTRODUCTION}

Estimating the rheological properties of a paste using convenient methods such as the slump technique are common practice within the industry. However, the universality of comparing slump heights to estimate the flow properties for different paste products has been questioned (Clayton et al., 2003; Paterson, 2002). The dispute relates to the fact that two paste products may in fact exhibit similar slump heights, but may not share the same shear yield strength since their densities may be different. This discrepancy is catered for by the method of Pashias et al. (1996) in which the shear yield stress can be conveniently calculated from the slurry density and the slump height.

However, certain paste rheological behaviours are observed which appear puzzling and which cannot be explained on the basis of particle size and slurry density alone. The chemical conditions of pastes (particularly those containing clay minerals) have profound effects on the colloidal interactions of the suspended solids and hence on the rheological behaviour of pastes (Vietti, 2004; Dunn, 2005).

This paper demonstrates that different slump heights may be observed for a kimberlite paste containing smectite at one material density, but varying paste chemical conditions.

\section{CLAY MINERAL COLLOIDAL PROPERTIES}

Due to the variety of resources exploited tailings generally contain a kaleidoscope of mineral types. However, in general the fine clay minerals tend to be concentrated within the tailings. Since, the colloidal properties of clay suspensions are highly sensitive to chemical conditions; their behaviour directly affects the operational performance of each aspect of the paste system from thickening to transport to deposition and rehabilitation. As such the clay minerals will be discussed in some detail in the following section.

\subsection{Clay size and structure}

Clays (or phyllosilicates) are typically classified on a size basis as the $-2 \mu \mathrm{m}$ fraction within a tailings slurry. However, a distinction must be made between the mineralogy of clay sized particles and true clay minerals (Fourie, 2002). True clays are classified into two major types based on the clay crystal lattice structure, namely 1:1 type clays (composed of a single octahedral layer which is bound to a single silicon tetrahedral layer), and 2:1 type clays (composed of two tetrahedral sheets sandwiching a central octahedral sheet) (Figure 1). 


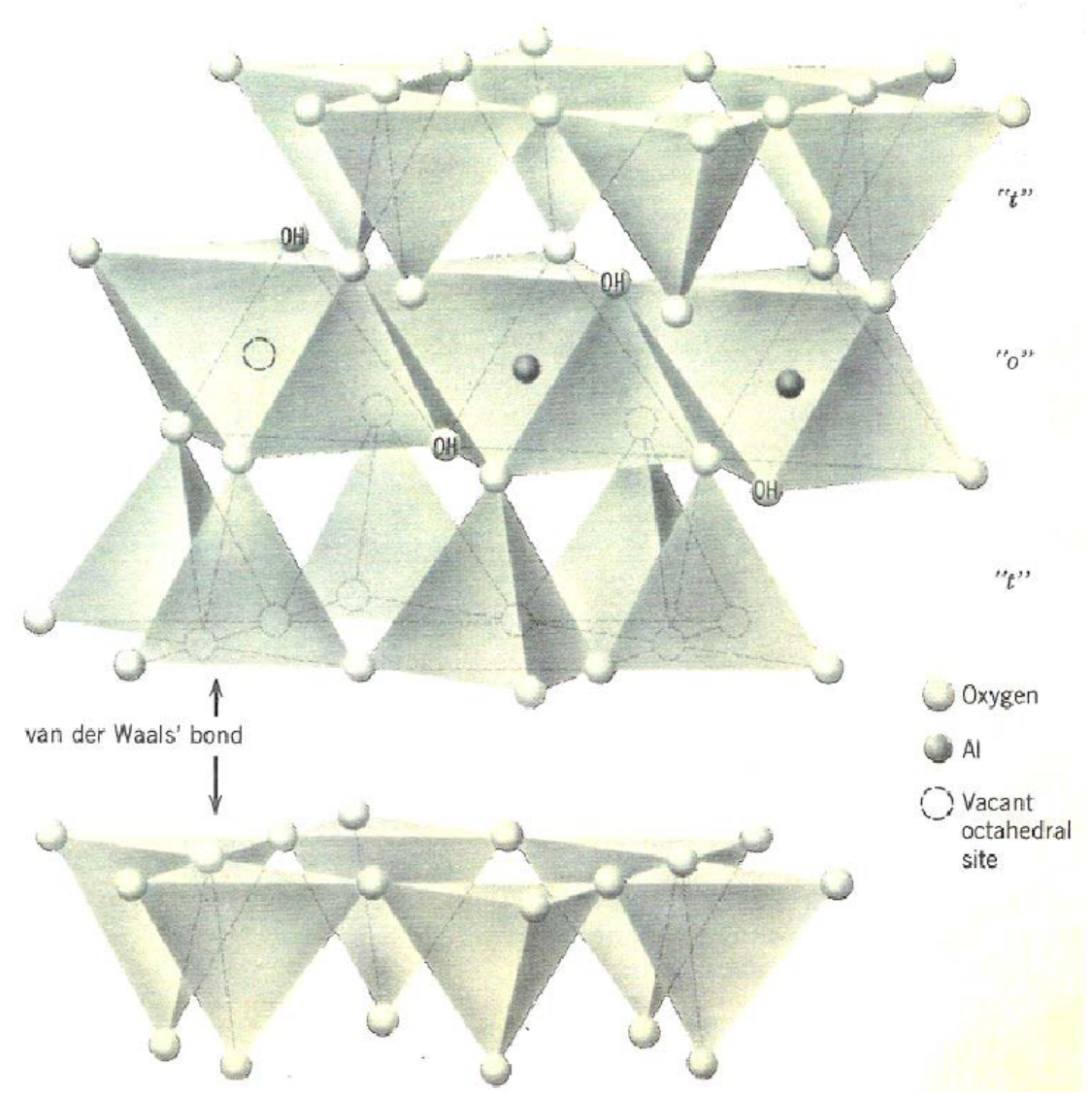

Figure 1 Crystal lattice structure of a typical 2:1 clay mineral (Klein, 2002)

Clays are further classified into eight major groups according to crystal structural features and charge characteristics (Table 1).

Table 1 Classification of phyllosilicates (Brindley and Brown, 1980)

\begin{tabular}{|c|c|c|c|}
\hline Type & $\begin{array}{c}\text { Group } \\
(\mathrm{x}=\text { charge per formula unit })\end{array}$ & Sub-group & Species \\
\hline $1: 1$ & $\begin{array}{c}\text { Serpentine - kaolin } \\
(\mathrm{x} \sim 0)\end{array}$ & $\begin{array}{l}\text { Serpentines } \\
\text { Kaolins }\end{array}$ & $\begin{array}{l}\text { Chrysotile, antigorite, lizardite } \\
\text { Kaolinite, dickite, nacrite }\end{array}$ \\
\hline \multirow{7}{*}{$2: 1$} & $\begin{array}{c}\text { Talc }- \text { pyrophyllites } \\
(\mathrm{x} \sim 0)\end{array}$ & $\begin{array}{l}\text { Talcs } \\
\text { Pyrophyllites }\end{array}$ & $\begin{array}{l}\text { Talc } \\
\text { Pyrophyllite }\end{array}$ \\
\hline & $\begin{array}{l}\text { Smectite } \\
\qquad(\mathrm{x} \sim 0.2-0.6)\end{array}$ & $\begin{array}{l}\text { Saponites } \\
\text { Montmorillonites }\end{array}$ & $\begin{array}{l}\text { Saponite, hectorite, sauconite } \\
\text { Montmorillonite, beidellite, nontroite }\end{array}$ \\
\hline & $\begin{array}{l}\text { Vermiculite } \\
\qquad(\mathrm{x} \sim 0.6-0.9)\end{array}$ & $\begin{array}{l}\text { Trioctohedral vermiculites } \\
\text { Dioctohedral vermiculites }\end{array}$ & $\begin{array}{l}\text { Trioctohedral vermiculite } \\
\text { Dioctohedral vermiculite }\end{array}$ \\
\hline & $\begin{array}{ll}\text { Mica } & \\
& (\mathrm{x} \sim 1.0) \\
\end{array}$ & $\begin{array}{l}\text { Trioctohedral micas } \\
\text { Dioctohedral micas }\end{array}$ & $\begin{array}{l}\text { Phlogopite, biotite, lepidotite } \\
\text { Muscovite, paragonite }\end{array}$ \\
\hline & $\begin{array}{l}\text { Brittle Micas } \\
\qquad(\mathrm{x} \sim 2.0)\end{array}$ & $\begin{array}{l}\text { Trioctohedral brittle micas } \\
\text { Dioctohedral brittle micas }\end{array}$ & $\begin{array}{l}\text { Clintonite, anandite } \\
\text { Margarite }\end{array}$ \\
\hline & $\begin{array}{l}\text { Chlorite } \\
\qquad(\mathrm{x} \sim \text { variable })\end{array}$ & $\begin{array}{l}\text { Trioctohedral chlorites } \\
\text { Dioctohedral chlorites }\end{array}$ & $\begin{array}{l}\text { Clinochlore, chamosite, nimite } \\
\text { Donbassite }\end{array}$ \\
\hline & $\begin{array}{c}\text { Sepiolite }- \text { palygorskite } \\
(\mathrm{x} \sim \text { variable })\end{array}$ & $\begin{array}{l}\text { Sepiolites } \\
\text { Palygorskites }\end{array}$ & $\begin{array}{l}\text { Sepiolites, loughlinite } \\
\text { Palygorskites }\end{array}$ \\
\hline
\end{tabular}


Due to their crystal structure, clay minerals are generally soft, flaky and may be leaf-like; needle-like or plate-like in shape. Up to 50 individual crystal layers (or lamellae) may be stacked upon one another to form colloidal sized clay tactoids or particles, which form the basic structural fabric within a soil or paste as depicted in (Tuller and Or, 2003; Tessier, 1990).

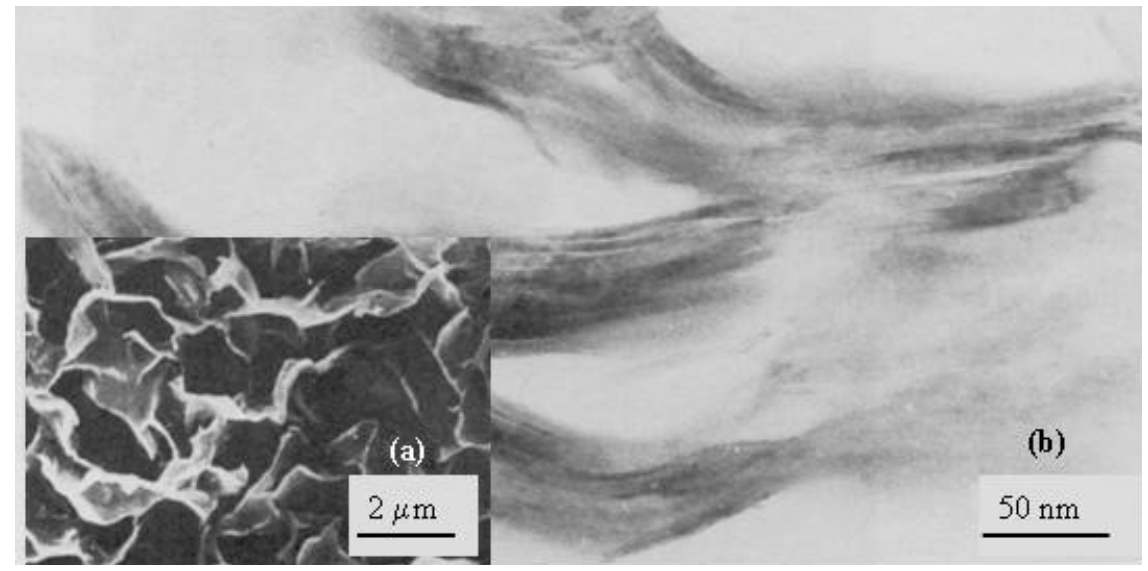

Figure 2 (a) Smectite tactoid particles; (b) Lamellae structure of tactoids (Tessier, 1990)

\subsection{Clay particle electrical charge}

The charge properties of clay minerals are largely a function of imperfections within the clay crystal lattice structure. Isomorphus substitution of an existing atom by another with a lower valance (for example $\mathrm{Mg}^{2+}$ for $\mathrm{Al}^{3+}$ in the octahedral layer) results in an excess negative charge, which is distributed at the particle surface. The excess negative charge is compensated for by the adsorption of cations onto the outer surfaces of the crystal lattice surface. Under hydrated conditions, the compensating cations may be exchanged by others from the solution depending on how strongly they are bound to the crystal surface. For this reason, they are known as exchangeable cations and their concentrations can be used as a measure of the amount of lattice charge or cation exchange capacity (CEC) of the clay (Van Olphen, 1977). Typically within the Smectite clay group, surface charge accounts for about $80 \%$ of the total CEC while the remainder is accounted for by the clay particle edges.

Clay edge charges can also significantly affect the behaviour of tailings slurries. Under saturated conditions, hydroxyl $\left(\mathrm{OH}^{-}\right)$groups associate themselves with the exposed silicon and metal atoms at the clay edges (Svarovsky, 1981). As a consequence, the $\mathrm{pH}$ of the surrounding environment profoundly affects clay particle edge charge. Under acidic conditions, the $\mathrm{OH}^{-}$bearing groups become protonated to carry an overall positive charge, leading to edge-to-face particle interactions which may result in particle aggregation and settling under gravity. As the $\mathrm{pH}$ is increased, the $\mathrm{OH}^{-}$groups will become de-protonated until a point of overall edge neutrality is achieved. This $\mathrm{pH}$ is known as the zero point of charge (ZPC) of the clay crystal edge. Further increases in $\mathrm{pH}$ will result in total de-protonation of the $\mathrm{OH}^{-}$groups until an overall negative edge charge dominates, allowing the clay particles to remain colloidaly dispersed as a consequence of negative particle repulsive forces (Figure 3). 


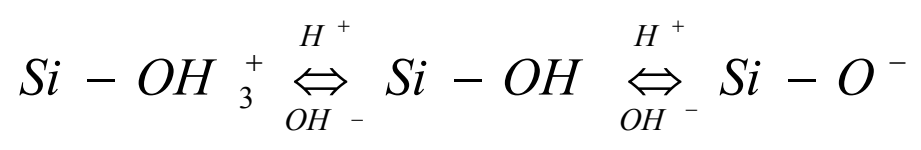

\section{Acidic \\ Neutral \\ Alkaline \\ Positive charge \\ Zero Point of Charge \\ Negative charge}

\section{Figure $3 \quad \mathrm{pH}$ dependency of clay edge charges}

\section{CLAY SLURRY BEHAVIOUR}

Soil scientists have long recognized the deleterious affects which salts may have on the behaviour of the clay component of an agricultural soil. In order to identify and treat such soils, a diagnostic system was developed in which certain chemical constituents of the soil and the irrigation water were measured and which then enabled the soil scientist to determine the potential hazard of the water to the soil (Richards, 1969). This diagnostic system is based upon three important mechanisms which affect the colloidal properties of clays within the soils, and by extension, to clays within mineral tailings.

\subsection{Suspended clay cation exchanged state}

The sodium-ion exchanged nature of clays within slurries can be expressed as the exchangeable sodium percentage (ESP) of the suspension. This measure provides an indication of the sodicity or amount of sodium ions bound to the clay fraction within the slurry. Slurries exhibiting clays with high ESP values tend to be highly alkaline and colloidally dispersive, while slurries exhibiting clays with low ESP values tend to be naturally coagulated and settling (Figure 4).

Another factor, which plays a vital role in determining the ESP value of clays, is the chemical quality of the metallurgical plant process water, which contacts the ore. The sodium adsorption ratio (SAR) value of the water is used to determine whether a process water quality is likely to create slurries, which are highly sodium ion-exchanged. The SAR is the ratio of sodium ions to calcium and magnesium ions in solution and the figures are derived from a normal chemical analysis of the water. 


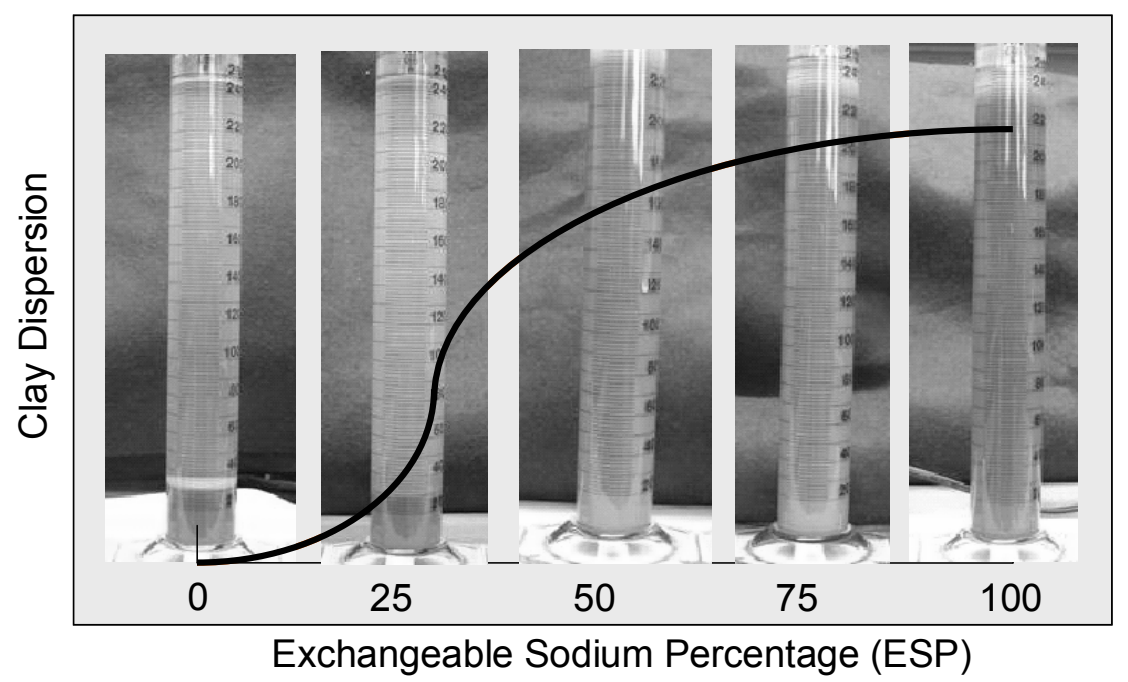

Figure 4 Effect of increasing sodicity on clay slurry dispersive behaviour (Vietti, 2004)

\subsection{Suspension $\mathrm{pH}$}

As mentioned earlier, the $\mathrm{pH}$ of the suspension greatly affects the charge associated with the clay particle edges. Below the clay edge ZPC, edge-to-face particle interactions may take place, resulting in particle aggregation and settling under gravity. At suspension $\mathrm{pH}$ values above the ZPC, clay slurries will tend to remain dispersed as a consequence of negative particle repulsive forces (Figure 5).

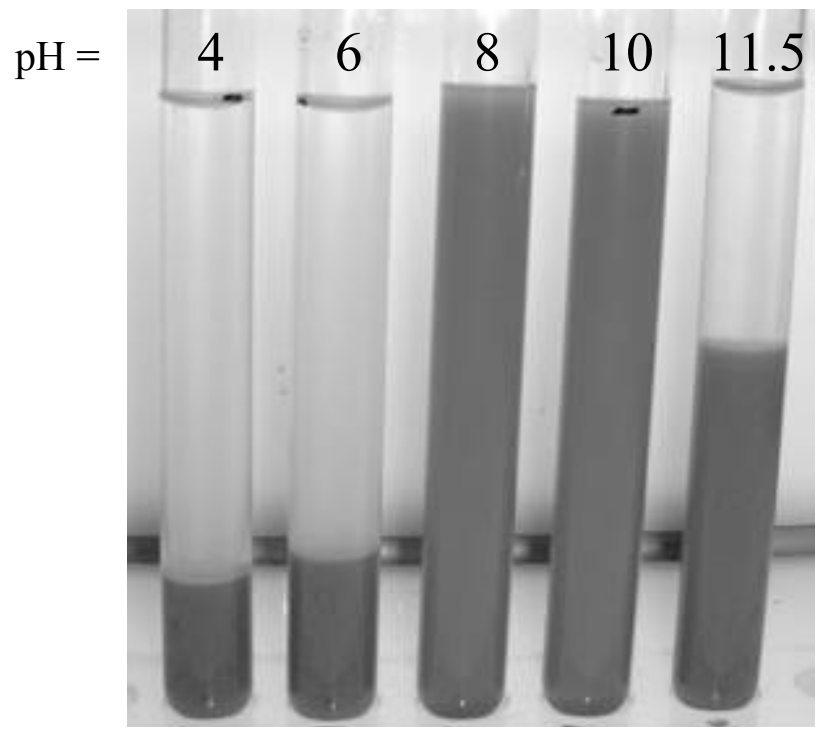

Figure $5 \quad$ Effect of suspension pH on clay slurry dispersive behaviour (Vietti, 2004)

\subsection{Suspension ionic concentration}

A third and overriding mechanism affecting the dispersive behaviour of low-density clay suspensions is the absolute ionic concentration of the suspension. At low ionic concentrations, slurries may remain dispersed 
due to double layer repulsing forces which keep the suspended particles from interacting. At high ionic concentrations, the $\mathrm{CCC}$ value of the suspension may be exceeded allowing particle aggregation and settling can occur (Figure 6).

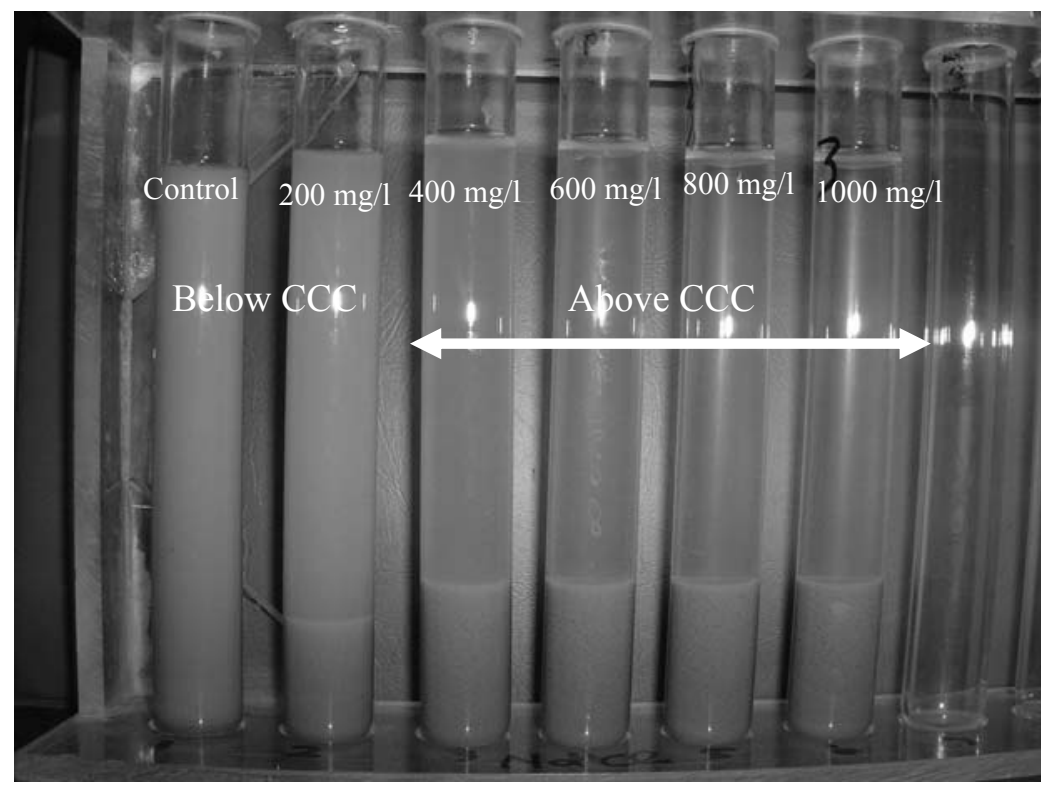

Figure 6 Effect of increasing salinity on clay slurry dispersive behaviour (Vietti, 2004)

The electrolyte concentration in the aqueous phase of slurries can be estimated by measuring the electrical conductivity of a slurry extract. The conductivity is an indicator of the salinity or amount of free watersoluble salts in the tailings, and is expressed as milliSiemens per centimetre $(\mathrm{mS} / \mathrm{cm})$.

\section{CLAY SLURRY BEHAVIOURAL MAPS}

By integrating the three mechanisms and determining their effect on clay suspensions, a "behavioural map" can be generated to describe the behaviour of the slurry under any possible colloidal condition. The map therefore can provide an explanation to the often confusing dispersion and rheological behavioural observations of smectite clay containing slurries (Vietti, 2004).

\subsection{Dispersion behaviour map}

By measuring some of the slurry parameters described above, it is possible to locate the position of a slurry on a behaviour map and predict its behaviour. Furthermore it is possible to alter the slurry chemical conditions such that a more desired slurry behaviour is attained (Figure 7). 


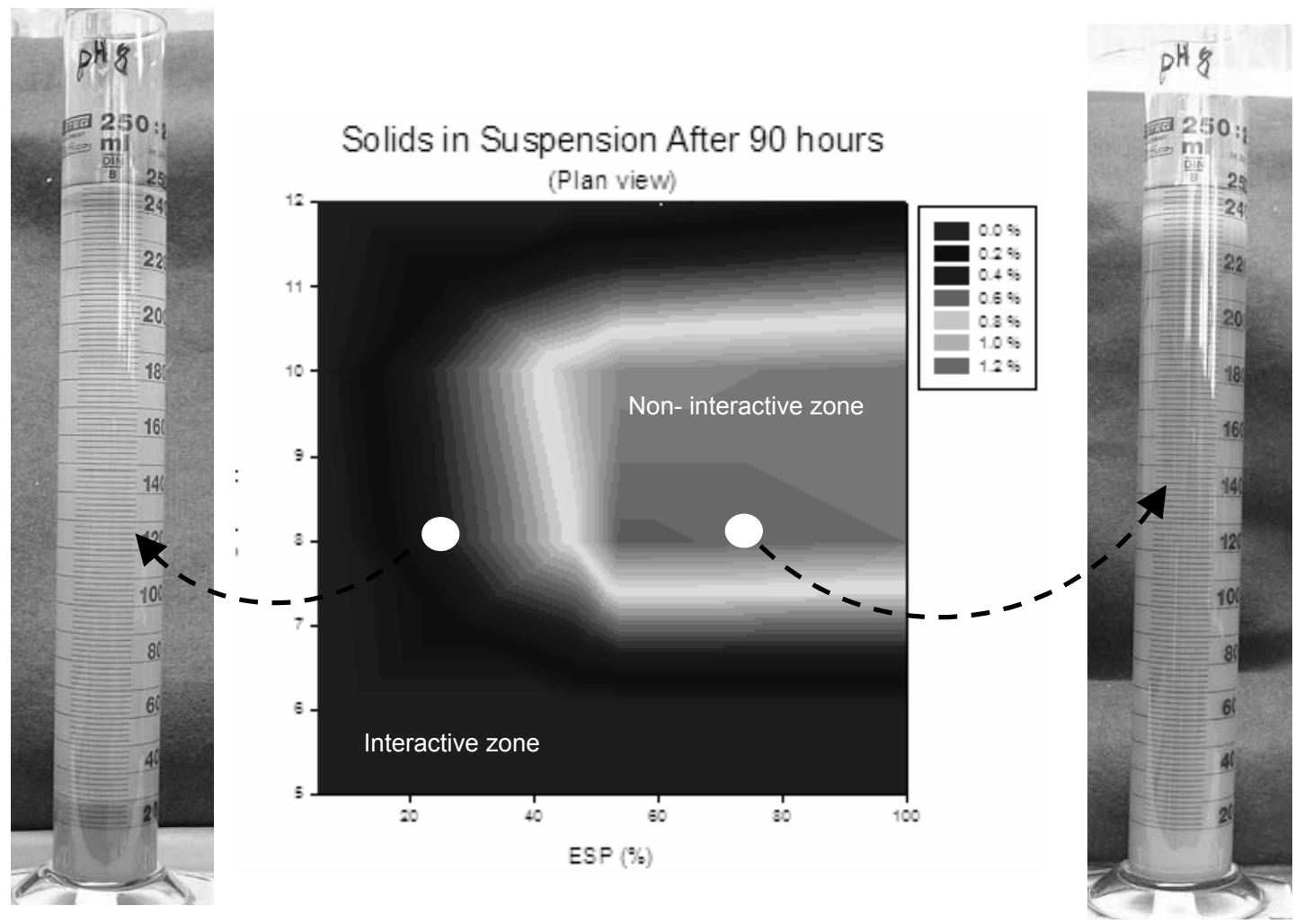

Figure 7 Dispersion behavioural map for a smectite clay slurry (Vietti, 2004)

\subsection{Rheology behaviour map}

The effects which slurry chemical conditions have on clay particle association and hence paste rheology are clearly demonstrated in Figure 8 in which a wide range of rheological behaviours are expressed by a single thickened kimberlite clay mineral paste. In this case, under certain colloidal conditions, the slurry $\left(\mathrm{d}_{50}\right.$ of 2 micron) was shown to have almost no yield strength at solids contents as high as $47 \%$ solids by mass, while in other conditions, it was shown to develop significant yield strength at comparatively low solids contents (30\% solids by mass).

These rheological observations, when simply related to the solids content within the paste provide no explanation of this apparently aberrant behaviour. However, if the same data are expressed as a function of slurry colloidal properties such as ESP and $\mathrm{pH}$ they can be explained by the clay particle association and orientation as depicted by the Scanning Electron Micrographs (Figure 9). 


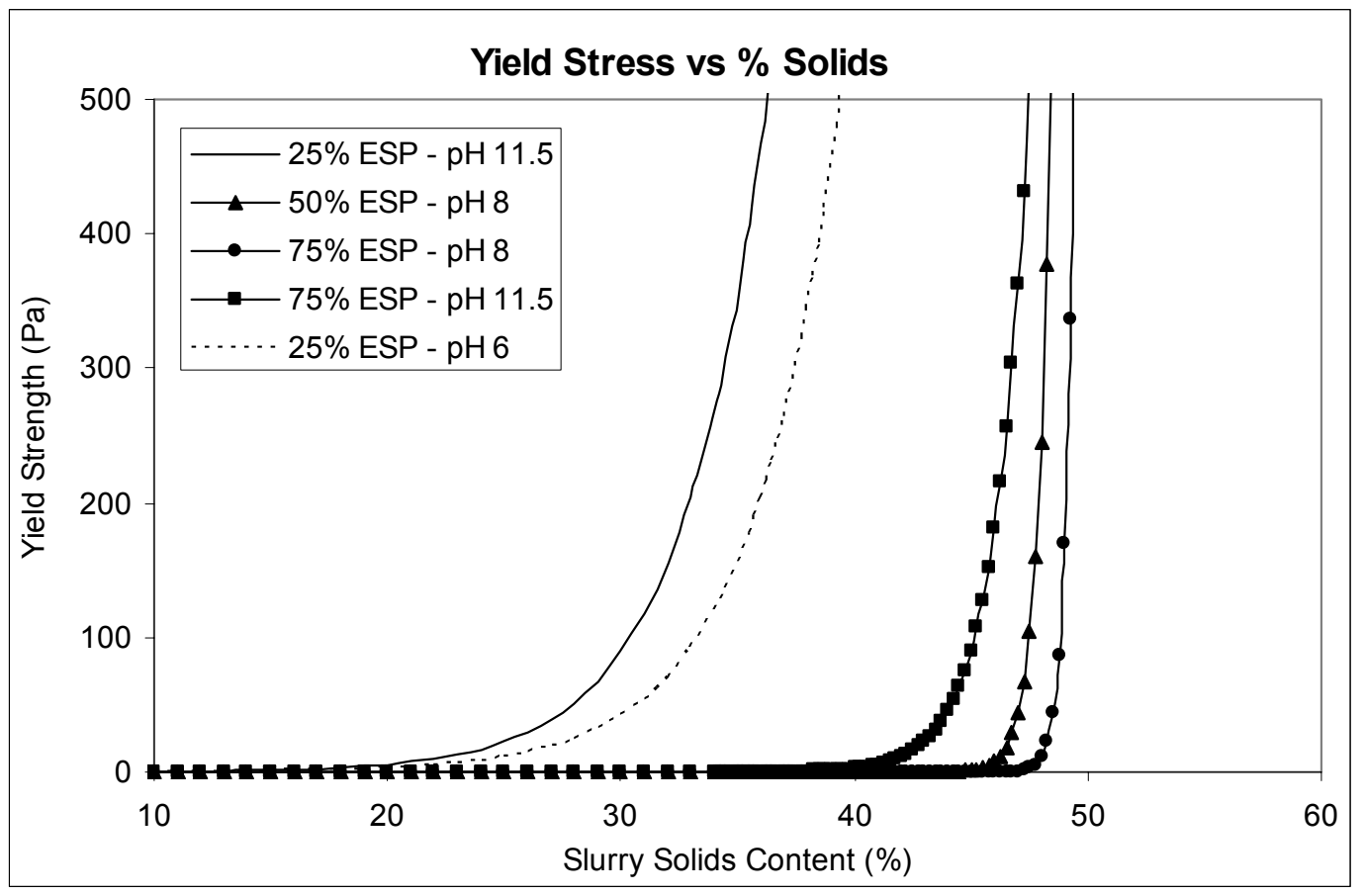

Figure 8 Effect of slurry colloidal properties on rheological behaviour of a single kimberlite clay mineral paste (Vietti, 2004)

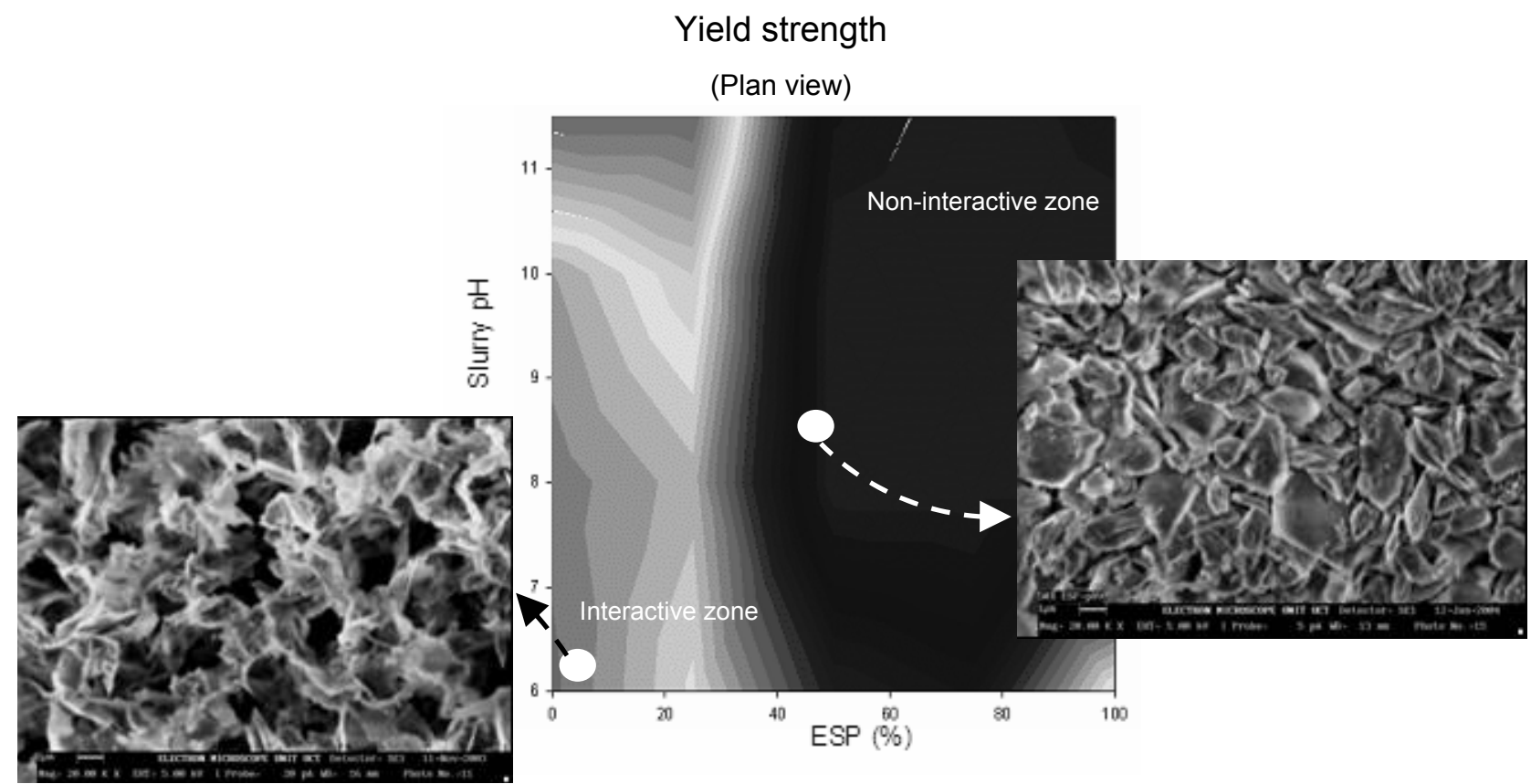

Figure 9 Rheological behavioural map for a smectite clay slurry at $38 \%$ solids (Vietti, 2004)

Distinct particle interaction zones can be identified. The "non-interactive zone" is characterised by limited or no particle interaction, resulting in colloidal stable or dispersive slurries and favourable paste flow behaviour (i.e. low yield strength). The "interactive zone", on the other hand is characterised by significant particle 
interaction, resulting in colloidally unstable or naturally coagulated slurries and poor paste flow behaviour (i.e. high yield strength).

\section{PASTE CHEMISTRY AND THE SLUMP TEST}

This section demonstrates how paste chemical conditions provide another dimension to the estimation of paste rheological properties by means of the slump test.

\subsection{Methods and materials}

A slurry was generated from a smectite clay containing kimberlite ore $(-300 \mu \mathrm{m})$ and distilled water, at a solids concentration of $9 \%$ by mass. The sample was flocculated at $42 \mathrm{~g} / \mathrm{t}$ using an anionic flocculant to generate a settled mud bed, which was subsequently isolated and sun dried to a high solids concentration paste material. Table 2 presents the paste material characteristics.

Table 2

Kimberlite paste material characteristics

\begin{tabular}{|l|l|}
\hline Parameters & \\
\hline Solids specific gravity & $2.4 \mathrm{~g} / \mathrm{cm}^{3}$ \\
\hline Particle size distribution & $75 \%<74 \mu \mathrm{m}$ \\
\hline Exchangeable Sodium Percentage (ESP) & $32 \%$ \\
\hline $\mathrm{pH}$ & 8.6 \\
\hline Paste solids concentration (by mass) & $55-70 \%$ \\
\hline
\end{tabular}

A slump test was performed on the paste sample at its natural $\mathrm{pH}(\mathrm{pH}$ 8.6) over a range of solids concentrations using a cylindrical mould as advised by Pashias et al. (1996). Table 3 presents the dimensions of the slump container.

Table $3 \quad$ Slump container dimensions

\begin{tabular}{|l|c|}
\hline Slump container & \\
\hline Material & PVC \\
\hline Shape & cylindrical \\
\hline Diameter & $105 \mathrm{~mm}$ \\
\hline Height & $130 \mathrm{~mm}$ \\
\hline Aspect ratio & 1.24 \\
\hline
\end{tabular}

A yield stress value was calculated from the slump height and paste density using the correlation provided by Pashias et al. (1996). A Paar Physica Rheolab vane rheometer was used to obtain a directly measured shear yield stress value on the same sample for comparison. Table 4 presents the vane dimensions. 
The procedure was repeated at two different paste suspension $\mathrm{pH}$ values ( $\mathrm{pH} 6.3$ and 11.5) by changing the suspension $\mathrm{pH}$ through the addition of hydrochloric acid and sodium hydroxide solutions.

\section{Table $4 \quad$ Vane dimensions}

\begin{tabular}{|l|l|}
\hline Vane & \\
\hline Diameter & $25 \mathrm{~mm}$ \\
\hline Length & $60 \mathrm{~mm}$ \\
\hline No. of blades & 4 \\
\hline
\end{tabular}

\section{$5.2 \quad$ Results}

Modification of the $\mathrm{pH}$ of the paste suspension, shifted colloidal behaviour of the particles in the material from a natural non-interactive state to an artificial interactive state as shown in Figure 10.

At similar solids content (approximately 65\% solids by mass), a paste sample in one colloidal condition was shown to have a shear yield strength in the order of $100 \mathrm{~Pa}$. When the colloidal conditions were altered, the same paste sample was shown to develop significant strength in the order of $400 \mathrm{~Pa}$ (Dunn, 2005).

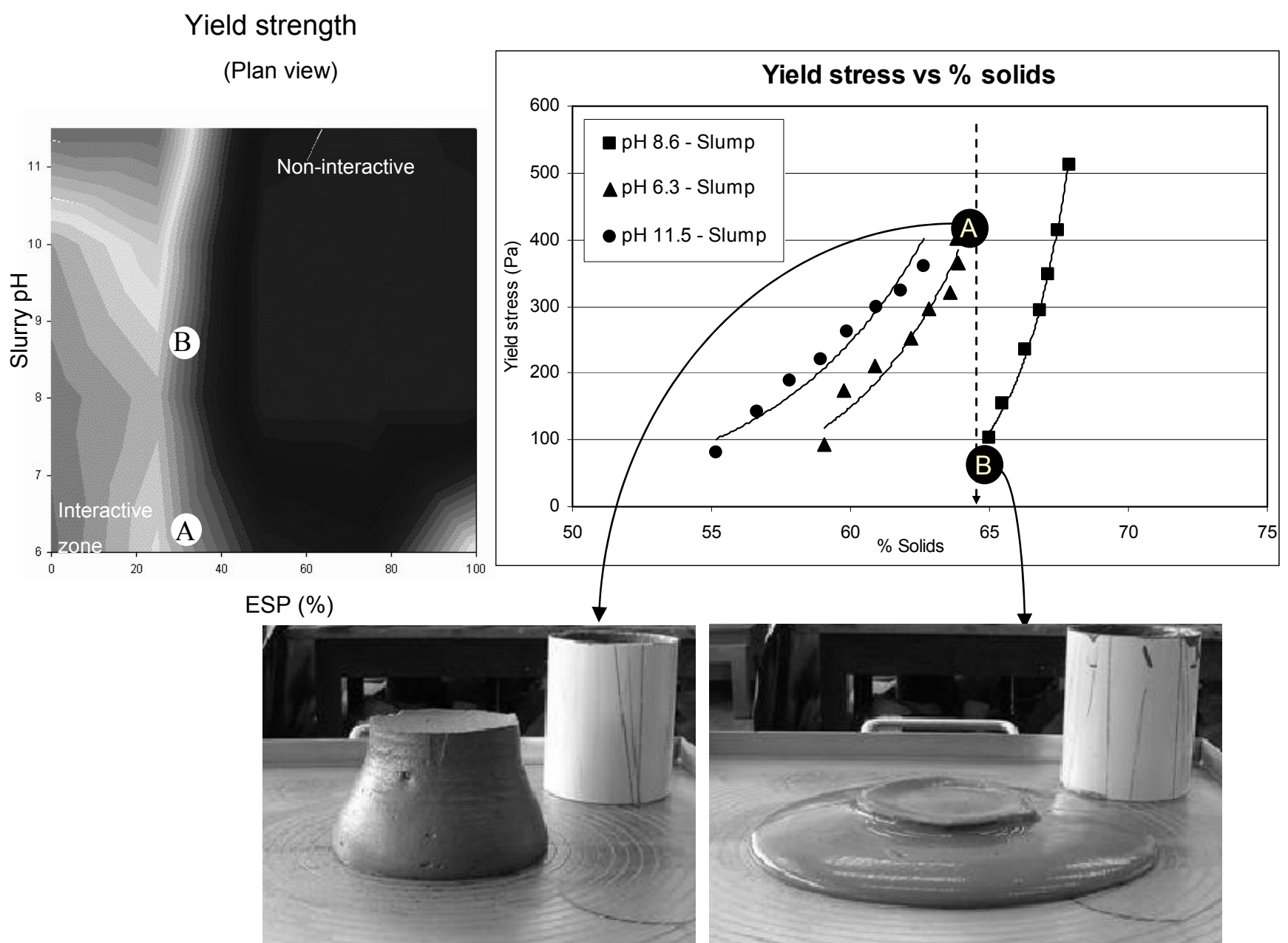

Figure 10 Effect of colloidal conditions on Smectite clay paste rheological behaviour 
Figure 11 demonstrates that the slump test provided a fairly accurate prediction of the paste material shear yield stress for a paste material in the interactive state $(\mathrm{pH} 6.3$ and $\mathrm{pH} 11.5)$. Significant underestimation of the shear yield stress was obtained with the slump test for a non-interactive paste at pH 8.6 (Dunn, 2005).

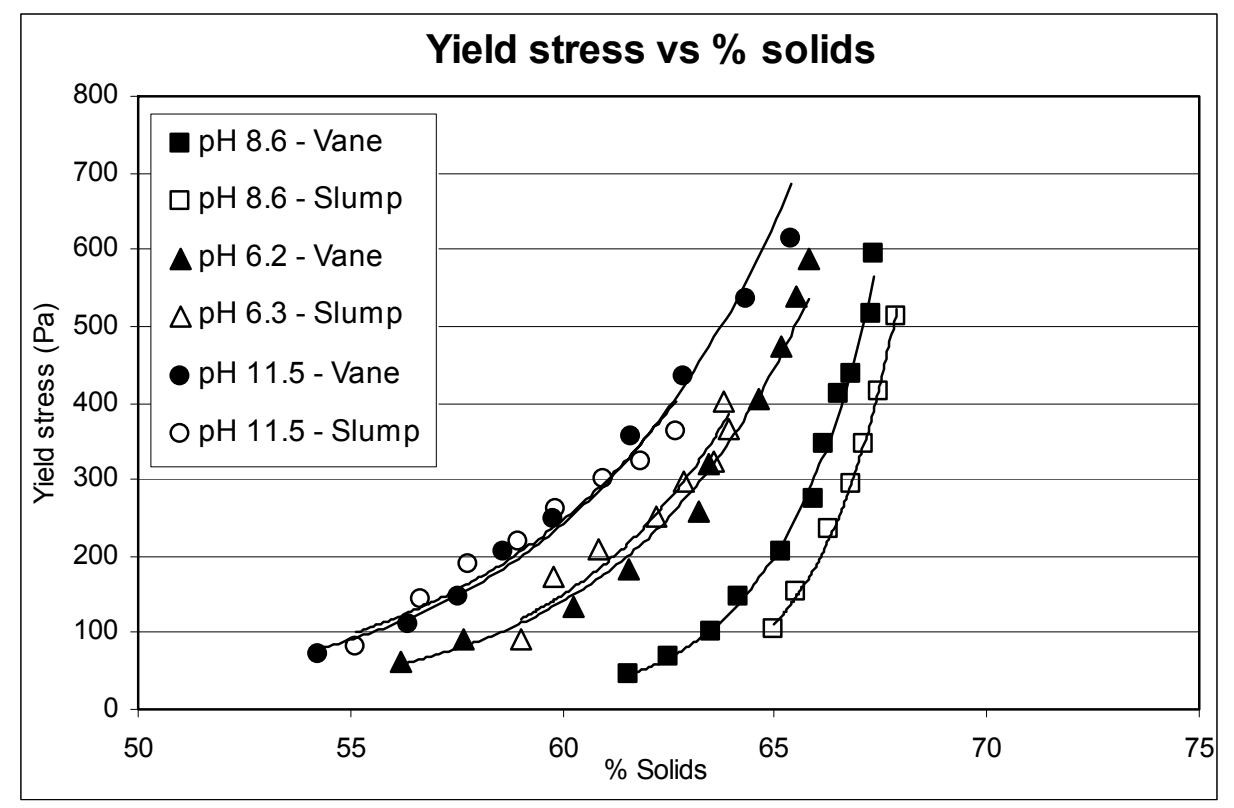

Figure 11 Correlation between calculated and measured yield stress values

\section{CONCLUSION}

The colloidal properties of thickened or paste slurries can have profound effects on the settling; consolidation and rheological behaviour, particularly mixtures containing clay minerals. Measuring and monitoring these properties allows the paste plant operator to gain an understanding of the tailings suspension characteristics and how it could be manipulated to match the paste system needs.

\section{REFERENCES}

Brindley, G.W. and Brown, G. (1980) Crystal structure of clay minerals and their X-ray identification, Brindley, G.W. and Brown, G. (eds.), Mineralogical Society, London.

Clayton, S., Grice, T.G. and Boger, D.V. (2003) Analysis of the slump test for on-site yield stress measurement of mineral suspensions, International Journal of Mineral Processing, Volume 70, pp. 3-21.

Dunn, F. (2005) A study of the relationship between various slurry material characteristics and the flow behaviour of co-disposed kimberlite tailings upon deposition, MSc thesis, University of the Witwatersrand, Johannesburg.

Fourie, A.B. (2002) Materials characterisation, Paste and thickened tailings - a guide, Jewell, R.J., et al. (eds), Australian Centre for Geomechanics, pp. 35-47.

Klein, C. (2002) Mineral Science (22 $2^{\text {nd }}$ edition), John Wiley \& Sons, New York.

Pashias, D.V., Boger, N.P., Summers, K.J. and Glenister, D.J. (1996) A fifty cent rheometer for yield stress measurement, J. Rheology, Vol. 40, No. 6, pp. 1179-1189.

Paterson, A. (2002) Is slump a valid measure of the rheological properties of high concentration paste slurries? Proceedings $15^{\text {th }}$ International Conference of Slurry Handling and Pipeline Transport, Banff, Canada.

Richards, L.A. (ed.) (1969) Diagnosis and improvement of saline and alkali soils, US Dept. Agriculture Handbook No. 60. 
Svarovsky, L. (ed) (1981) Solid-liquid separation (2 $2^{\text {nd }}$ edition), Butterworths, London.

Tessier, D. (1990) Behaviour and microstructure of clay minerals. Soil colloids and their associations in aggregates, M. F. De Boodt et al., (eds.), Plenum Press, New York, pp. $387-415$.

Tuller, M. and Or, D. (2003) Hydraulic functions for swelling soils: Pore scale considerations, Journal of Hydrology, pp. 50 - 71.

Van Olphen, H. (1977) Clay colloid chemistry, John Wiley \& Sons, New York.

Vietti, A.J. (2004) Know your chemistry - Suspension and compaction behaviour of paste, International Seminar on Paste and Thickened Tailings, Paste 2004, 31 March - 2 April 2004, Cape Town, South Africa. 